ŁUKASZ WOJTKOWSKI

Instytut Politologii UMK

\title{
Ideologiczne ujęcie relacji mediów i polityki
}

\section{Media a polityka}

edia masowe i polityka to swoiste zbiory, które możemy analizować jako wzajemnie powiązane, ale odrębne od siebie systemy. Choć z drugiej strony nie będzie błędem traktowanie ich jako subsystemów wchodzących w skład ogólnego systemu społecznego. Jednak już pobieżne próby opisania relacji, jakie zachodzą na styku tych systemów nastręczają trudności. Po pierwsze dlatego, że są to elementy na tyle dynamiczne, że wymykają się podstawowym narzędziom badawczym. Po drugie, charakteryzuje je pewna interdyscyplinarność. W zależności od tego, czy będziemy próbowali analizować je z punktu widzenia politologii, komunikacji społecznej czy medioznawstwa, za każdym razem nasza uwaga skupi się na jednych zmiennych, pomijając jednocześnie inne. $W$ analizach styku mediów i polityki można zauważyć pewien trend, dążący do opisania ich w sposób modelowy. Te z kolei oparte są na - już istniejących i odpowiednio nadbudowanych - koncepcjach ideologicznych.

Mimo prób charakterystyki, jaką rolę we wzajemnych relacjach pełnią media masowe i polityka, na plan pierwszy wysuwa się obraz niejednolitego, skomplikowanego zjawiska. Dlatego najważniejsza wydaje się arbitralna operacjonalizacja i kategoryzacja, która pozwoli owym relacjom przypisać ramy teoretyczne, na potrzeby artykułu . Przy czym podstawowym rozróżnieniem modeli będzie umieszczenie ich na biegunach koncepcji liberalnych i lewicowych. Podobnego podziału, nawiązując do politycznych funkcji mediów 
masowych, dokonał Tomasz Goban-Klas ${ }^{1}$, określając relacje te mianem doktryn medialnych. Za Fredem S. Siebertem, Theodorem Petersonem i Wilburem Schrammem ${ }^{2}$ wyróżnił doktrynę autorytarną, liberalną, komunistyczną i odpowiedzialności społecznej. Choć autorzy skupili się na prasie jako głównym obiekcie analiz, to ich modele są dyskutowane i wykorzystywane do dziś. Zaś najlepsze wydaje się ogólne rozróżnienie dokonane przez Andrew Heywooda ${ }^{3}$, który spośród wielu teorii wyróżnia cztery ujęcia: dominującej ideologii, pluralistyczne, rynkowe i wartości elitarnych. Z punktu widzenia zastosowania ideologii najważniejszymi są pierwsze trzy. Zaproponowana typologia znajduje najpełniejsze odzwierciedlenie w literaturze politologicznej i dotyczącej komunikacji masowej, choć często kryje się pod różnym aparatem pojęciowym. Zastosowanie takiej kategoryzacji pozwoli określić względnie przejrzyste ramy klasyfikacyjne relacji media masowe - polityka.

\section{Model ideologii dominującej}

Model ideologii dominującej jest jednym z najszerzej omówionych w literaturze przedmiotu, a jego początków należy szukać w marksistowskim podejściu do komunikacji politycznej. Z tej perspektywy akt komunikacji politycznej nie odbiega od innych wzorców relacji społecznych, które oparte są na modelu baza - nadbudowa. Grupa posiadająca aktualnie władzę musi kontrolować swoje interesy klasowe, a media są podstawowym narzędziem tej kontroli. Rola mediów sprowadza się zasadniczo do pokazywania określonych poglądów i wartości w kategoriach uniwersalnych, tak, aby korespondowały z przekonaniami zwykłych ludzi, jako najważniejsze i racjonalne opinie o świecie. Klasa panująca sprawuje kontrolę nad wszystkimi instytucjami medialnymi, państwowymi i prywatnymi ${ }^{4}$. To właśnie ideologia odgrywa najważniejszą rolę, bowiem poprzez nią klasy posiadające mogą głosić idee dominujące $\mathrm{w}$ danej epoce. $\mathrm{W}$ podejściu klasycznym duży nacisk położony został na ekonomikę mediów masowych. Baza bowiem staje się tu punktem centralnym analizy relacji media - polityka. Taki determinizm w nieunikniony sposób prowadzi do pominięcia i niedoceniania roli nadbudowy.

Jej rolę dostrzegł Louis Althusser, francuski filozof marksistowski, który dostrzegł pewną niezależność nadbudowy względem bazy. Stwierdził, że stosunki społeczne niezbędne do podtrzymania kapitalistycznego typu pro-

Zob. T. Goban-Klas, Media $i$ komunikowanie masowe. Teorie $i$ analizy prasy, radia, telewizji i Internetu. Warszawa, Kraków 2001, s. 159.

Zob. F.S. Siebert, T. Peterson, W. Schramm, Four Theories of the Press, Urbana 1956.

A. Heywood, Politologia, Warszawa 2006, s. 257.

K. Marks, F. Engels, Ideologia niemiecka, w: K. Marks, F. Engels. Dzieła, t. 3, Warszawa 1961. 
dukcji są utrzymywane przez ideologiczne instytucje państwowe, w tym media masowe. Analiza mediów zaproponowana przez Althoussera miała przede wszystkim ukazać jak rządzący legitymizują poglądy i idee poprzez media. Jednym z głównych punktów jego ujęcia zdawał się być indywidualizm. Traktowany jako najważniejszy element przekazu mediów masowych, powodujący niejako rozbijanie więzów społecznych (ludzie nie traktują siebie jako członków grupy) i sprzyjający kapitalizmowi. Jednak za najważniejszą w teorii Althoussera należy uznać koncepcję interpelacji, czyli przywoływania. Według tej teorii media masowe przywołują odbiorców i w ten sposób kreują u nich określone stanowiska względem tego, co konsumują ${ }^{5}$. Odbiorcy traktowani są jako jednostki, które poprzez swój indywidualizm błędnie rozumieją sytuację w której się znajdują. Nie są bowiem twórcami ideologii, a jedynie jej podlegają. Stąd istotna rola mediów, które poprzez przekaz skierowany do tak rozumianych jednostek, transmitują określony, uprzednio przygotowany, światopogląd. Jednostki zaś sadzą, że same ów pogląd wykreowały, nie widząc, jak bardzo są manipulowane przez klasy posiadające. $\mathrm{W}$ powyższej wizji można łatwo zaobserwować rolę, jaką mediom przypisywali klasycy koncepcji marksistowskiej. Traktowali je głównie jako narzędzie służące grupom uprzywilejowanym w kontrolowaniu potrzeb społecznych.

Ponadto, pierwsze koncepcje ideologii dominującej największą rolę $\mathrm{w}$ akcie komunikacji politycznej jednoznacznie przypisują klasom posiadającym. W korespondencji z takim ujęciem pozostaje również podejście Antonio Gramsciego, nazywane hegemonicznym. Gramsci sugerował, że media propagują idee burżuazyjne i kapitalistyczne, chcąc w ten sposób osiągnąć całkowitą dominację wartości określonej klasy. Głównym narzędziem mediów $\mathrm{w}$ takiej promocji jest przedstawianie owej grupy jako najlepszej do reprezentacji interesów całego społeczeństwa. Poprzez medialną dystrybucję i społeczną redystrybucję swoich idei klasa rządząca włada dzięki swoistemu przyzwoleniu innych klas, nie zaś przez przymus ${ }^{6}$. Na podstawie teorii Gramsciego można wnioskować, że to klasy niższe zgadzają się na sprawowanie kontroli przez grupy posiadające. Dzięki odpowiedniej dystrybucji idei następuje renegocjacja społecznego porządku, który wciąż sprzyja posiadającym. Zatem same teksty medialne nie są jedynie środkiem narzucania danych idei. Ważniejsze w tym punkcie są z pewności instytucję medialne, które stają się kreatorem przekazu.

L. Taylor, A. Willis, Medioznawstwo. Teksty, instytucje i odbiorcy, Kraków 2006, s. 33.

Tamże, s. 34. 
Wpływ przytoczonych powyżej klasycznych ujęć odegrał niebagatelną rolę we współczesnej koncepcji ideologii dominującej, szczególnie w teorii amerykańskiej. Za jej najbardziej wpływowych przedstawicieli uważa się Noama Chomskiego i Edwarda Hermana. W swojej pracy Manufacturing Consent: The Political Economy of the Mass Media ${ }^{7}$ opisali model nazwany propagandowym, w którym wyróżnili pięć filtrów, przez które wiadomości i relacje polityczne są zniekształcane $\mathrm{w}$ ramach struktury medialnej. $\mathrm{W}$ nawiązaniu do wyżej wymienionych teorii, autorzy twierdzili, że media masowe charakteryzuje instytucjonalna stronniczość, dzięki której poglądy elit posiadających mogą być popularyzowane. Taka popularyzacja odbywa się ich zdaniem poprzez propagandowe kampanie (kampanie dominującej ideologii). Niemniej jednak Chomsky i Herman ujęli w swoim modelu możliwość zaistnienia wewnątrzsystemowej dyskusji, sporu a nawet sprzeciwu. Pod warunkiem jednak zachowania podstawowych zasad funkcjonowania systemu, zatem dalszego utwierdzania niepodważalnych poglądów elit.

Najistotniejsza w ich teorii była enumeracja owych filtrów, które pokazują, jak w modelu propagandowym powstają wiadomości polityczne ${ }^{8}$.

Pierwszy obejmuje postawę rynkową korporacji medialnych, ze szczególnym uwzględnieniem wielkości kapitału finansowego potrzebnego do prowadzenia głównych tytułów medialnych, zapewniania władzy i dobrobytu właścicielom oraz koncentracji na rynku. Co więcej, serwisy informacyjne zwykle multiplikują i podtrzymują stanowisko elit politycznych, medialnych i biznesowych, które pozostają ze sobą w bliskich i zażyłych relacjach. o kolejności materiałów i ich objętości decydują właściciele mediów i poszczególne rządy. Dodatkowo na formę tego filtra wpływają same organizacje medialne, których najważniejszym zadaniem jest uzyskanie jak największego zysku ekonomicznego.

Drugi filtr pokazuje, jak na produkowane i przedstawiane wiadomości oddziałują reklamy i reklamodawcy. Herman i Chomsky uważali, że to właśnie zleceniodawcy reklam mają najważniejszy wpływ na przetrwanie i dobrobyt mediów masowych. To dzięki ich finansowaniu media komercyjne mogą funkcjonować prawidłowo. Zaś celem, zarówno reklamodawców jak i mediów masowych, jest dotarcie do jak najszerszej liczby potencjalnych klientów. Zatem oba te podmioty będą pomijały nadawców o małym zasięgu, głoszących niepopularne poglądy, które mogą podważać idee zakupów i konsumpcji.

Zob. E. S. Herman, N. Chomsky, Manufacturing Consent: The Political Economy of Mass Media, New York 1988.

8 Tamże, s. 3-31. 
Trzecim filtrem jest zależność mediów masowych od źródeł eksperckich. Zdaniem autorów wzrastająca zależność od danych politycznych czy ekonomicznych pochodzących ze źródła rządowego, jest korzystna dla dziennikarzy i mediów. Dzięki ich szerokiej dostępności media mają aktualne, twarde dane, co czyni relacje medialne znacznie bardziej wiarygodnymi. Dodatkowo, ów dostęp ułatwia pracę dziennikarzom, a to przekłada się na relatywną szybkość i łatwość tworzenia ram materiału informacyjnego. Takie działania znajdują odbicie w medialnej rzeczywistości, która odzwierciedla jedynie realia promowane przez rząd i koncerny medialne, utrudniając tym samym możliwość medialnego zaistnienia niezależnych ekspertyz czy analiz.

Czwarty filtr dotyczy zależności mediów od tzw. gromów (flak), czyli negatywnych reakcji na publikacje medialne. Przy czym owe skargi moga być przedstawiane zarówno przez osoby prywatne, publiczne jak i całe instytucje polityczne z rządem i sztabami kampanijnymi na czele. Zaś ich skutek dla medium może okazać się dotkliwy finansowo. Skargi bowiem, mogą znajdować swój finał w postaci odpowiedniego prawodawstwa. Co uniemożliwia mediom prowadzenie swojej właściwej działalności, rzutuje również na współpracę z reklamodawcami.

Piąty filtr to ideologia antykomunistyczna, która staje się elementem kontroli politycznej. Herman i Chomsky używają tego pojęcia jako szerokiego corralu, w obrębie którego władza może zakwalifikować wszystko, co jest niezgodne z medialnie utwierdzonym poglądem elit. Zatem wszelki radykalizm i odchylenie względem linii prezentowanej przez rząd i koncerny medialne staje się natychmiast przedsięwzięciem antysystemowym, piętnowanym przez media. Owocuje to kreowaniem jasnego i spolaryzowanego podziału w przestawianej rzeczywistości medialnej na dobro (w domyśle dobre dla systemu, obywateli i państwa) i zło (zaprzeczenie i zagrożenie dla systemu medialnego i politycznego).

Finalnym produktem takiej filtracji jest wiadomość, news publikowany na antenach mediów masowych, a zatem sprzedawany prawie całemu społeczeństwu, które $\mathrm{w}$ rzeczywistości nie może mu się przeciwstawić, bowiem takich postaw jest skutecznie oduczane. Takie ujęcie jest jednak nadto uogólniające. Bowiem prosystemowe media masowe różnią się w procesach produkcji i selekcji tematów, szczególnie politycznych. Herman i Chomsky sądzą, że jest to zjawisko wpisujące się w teorie propagandy. Media czynią tak celowo, aby stworzyć pozory pluralizmu poglądów. Różnice te są wciąż zgodne z szeroko rozumianym poglądem elit. Zaś idee opozycyjne wobec linii elit nigdy nie będą miały dostępu do mediów masowych sterowanych przez koncerny medialne i rządy. 
Wydaje się, że teoria zaproponowana przez amerykańskich klasyków zdecydowanie upraszcza relacje mass mediów i polityki. Za podstawową słabość modelu propagandowego należy uznać nadmiernie zaakcentowany determinizm ekonomiczny organizacji medialnych. Można sądzić, że autorzy traktują media jako swoiste, niemal tajemne organizacje, których głównym zadaniem jest kreowanie nieistniejącego porządku, propagowanie interesów elit politycznych i ekonomicznych. Choć faktycznie element ekonomii mediów masowych ma znaczący wpływ na tworzenie wiadomości politycznych, to jednak autorzy niewystarczająco podejmują kwestie działań poszczególnych dziennikarzy i rolę ich osobistych przekonań i poglądów. Za kolejny słaby punkt systemu propagandowego, choć wynikający oczywiście z założeń metodologicznych badań, należy uznać wąską możliwość odniesienia do innych porządków medialnych niż amerykański. Podejmując się analizy relacji mediów i polityki na gruncie polskim, szybko okaże się, że filtry drugi, czwarty i piąty nie znajdują zastosowania w kreacji wiadomości politycznych. Nie ma bowiem podstaw, aby sądzić, że reklamodawcy wpływają pośrednio lub bezpośrednio na produkcję wiadomości politycznych (za wyjątkiem reklam politycznych, ale tu zastosowanie ma odmienny mechanizm wpływów). Ponadto, koncerny medialne zdają się odporne na siłę rodzimych „gromów”, a i same skargi są zwykle nie dość skuteczne (pomijając nieliczne wyjątki), aby wywrzeć znaczny wpływ na kształt politycznych wiadomości. Wreszcie ideologia antykomunistyczna, w kraju gdzie media publiczne przez szereg lat pozostawały pod pośrednim zwierzchnictwem organizacji wywodzących się z systemu komunistycznego, zdaje się nie mieć dużego oparcia w rzeczywistości politycznej i medialnej. Faktem jest, że po zmianie rządów w 2005 roku media publiczne starały się, i niekiedy nadal to robią, dokonywać jaskrawego podziału piętnującego wszystko co związane z poprzednim systemem władzy. Jednak $\mathrm{w}$ porównaniu $\mathrm{z}$ amerykańską rzeczywistością zimnowojennej propagandy i walki politycznej to jedynie ułamek wykorzystania tego filtra. Co więcej, filtr ten nie znajduje również zastosowania w aktualnej rzeczywistości politycznej USA. Zapewne dlatego autorzy w reedycji książki z 1994 roku zastąpili go niekwestionowaną wiarą w korzyści konkurencji rynkowej i kapitalizmu konsumpcyjnego. Choć równie dobrym substytutem jest podział, obserwowany w USA od zamachów na WTC, kiedy to rząd i media masowe piętnowały wszelkie postawy sprzeciwu wobec polityki gabinetu określając je mianem unpatriotic i unamerican. 


\section{Model pluralistyczny}

Model pluralistyczny jest równie popularny w literaturze przedmiotu co opisany w poprzednim punkcie model ideologii dominującej. Często jest opisywany w podobnych kategoriach co model liberalny (wolnorynkowy) scharakteryzowany w kolejnym punkcie. Jednak w opozycji do poprzedniego ujęcia, media masowe traktowane są tu jako pozytywny aktor relacji ze światem zewnętrznym. Media spełniają tu głównie dwojaką rolę. Po pierwsze, są przekaźnikiem informacji, swoistym pośrednikiem między światem polityki i odbiorcami. Głównym punktem takiego założenia, jest wiara w obiektywizm relacji dziennikarskich i chęć odzwierciedlenia politycznej rzeczywistości bez wpływania na nią. Już w tym momencie winna nasuwać się konstatacja, że taki stan „czystego” przekazywania informacji jest w mediach niemal nieosiągalny. Media bowiem, już w trakcie zbierania informacji, dokonują subiektywnego wyboru najważniejszych z nich, całkowicie pomijając inne. Zatem pierwsza funkcja mediów jako przekaźnika informacji zdaje się prawidłowa, jedynie kiedy nie poddamy analizie tematu owej transmisji. Również wartość mediów traktowanych jako przekaźnik jest istotna jedynie jeśli będzie się je analizować jako szeroko dostępne dla różnych grup społecznych. Co można wyraźnie zaobserwować w przypadku nowych mediów, których względna łatwość obsługi i małe koszty eksploatacji powodują wzmocnienie pluralizmu i politycznej rywalizacji. Dzięki szerszej dostępności, nowe media stały się szybko rozwijającą platformą komunikacji politycznej. To z kolei dało znacznie większe możliwości komunikacyjne grupom politycznym dotąd pomijanym przez media tradycyjne. Jednakże wciąż pod znakiem zapytania pozostaje skuteczność komunikacji poprzez nowe media, szczególnie w kontekście dotarcia do jak najszerszych grup odbiorców.

Po drugie, media masowe spełniają rolę gwaranta procedur demokratycznych i pierwszego nadzorcy władzy. Możemy tu zatem mówić o mediach jako czwartym stanie czy sprawowaniu roli watchdoga. Media masowe dzięki przekazywaniu aktualnych informacji biorą aktywny udział w kształtowaniu opinii publicznej. Ta z kolei umożliwia racjonalną kontrolę działań władzy. Stąd wywodzi się przekonanie o mediach jako czwartym stanie ${ }^{9}$, który udostępnia społeczeństwu wiedzę z zakresu funkcjonowania państwa, stwarzając jednocześnie przestrzeń dla rozwijania wolnego rynku idei ${ }^{10}$. Również

Błędne jest tłumaczenie angielskiego forth estate jako czwarta władza. Bowiem media masowe nie są władzą sensu stricte. Zaś oryginalne angielskojęzyczne sformułowanie odnosiło się do roli mediów jako kolejnego obok duchowieństwa, arystokracji i mieszczaństwa stanu.

10 S. Allan, Kultura newsów, Kraków 2006, s. 52. 
w przypadku traktowania mediów jako watchdoga, stróża, który dokładnie analizuje wszelkie posunięcia władzy i polityków, model pluralistyczny opiera się na przekonaniu o niezbędnej wolności prasy. Media zatem odgrywają dużą rolę w utrzymywaniu równowagi politycznej i demokracji. Ponadto, ów pluralizm odnosi się do wewnętrznej struktury mediów, gdzie dziennikarze, właściciele, szefowie redakcji mają często odmienne poglądy ${ }^{11}$.

Jeśli jednak przyjmiemy, że media masowe w modelu pluralistycznym prowadzą dialog wewnątrz organizacji, to jednocześnie należy założyć, że już na tym poziomie może dochodzić do konfliktów. Mogą one z kolei prowadzić do promocji jedynie określonej idei, pomijając inną. W efekcie czego, stanowisko dziennikarza może być podważone przez zwierzchnika, a dana sprawa pominięta lub celowo zaakcentowana. Ponadto, traktując media jako czwarty stan czy stróża władzy, trzeba zadać pytanie czy takie dziennikarstwo jest od polityki niezależne? Wydaje się, że taki idealistyczny model mediów w relacji z polityką jest niemal nieosiągalny na szerszą skalę. Związki dziennikarzy ze światem polityki są coraz silniejsze i niekiedy granica między sprawowaniem funkcji kontrolnych a uzależnieniem od polityków jest niewidoczna. Szczególnie w przypadkach, kiedy znajomości przedstawicieli obu analizowanych sfer są więcej niż zawodowe. W tym miejscu należy zgodzić się z Robertem McChesneyem ${ }^{12}$, który pisze, że dziennikarstwo nigdy nie będzie całkowicie niezależnym przedsięwzięciem. Wymaga bowiem wsparcia instytucjonalnego i różnorodnych subsydiów. Ponadto w tworzenie wiadomości zaangażowany jest szereg osób ingerujących w proces decyzyjny, począwszy od dziennikarzy, przez wydawców, po tych, którzy ich zatrudniają.

\section{Model rynkowy}

Główną osią modelu rynkowego jest pojęcie wolnej konkurencji, w ramach której funkcjonują koncerny medialne. Ich głównym zadaniem jest zdobycie jak największych udziałów w rynku i maksymalizacja zysków. W tym celu media starają się dotrzeć ze swoim przekazem do jak najszerszej liczby potencjalnych odbiorców, co powinno przełożyć się na wymierne korzyści finansowe. Jeśli zatem media są jedynie wolnorynkowym graczem, to ich polityczne funkcje pełnią rolę drugoplanową. Nadawcy bowiem nie zaryzykują jakichkolwiek prób ingerencji w świat polityki, gdyż mogłoby to zniechęcić do odbiorców, dzięki którym funkcjonują. Również sam komunikat polityczny przekazywany przez koncerny medialne jest jedynie odtworze-

Tamże, s. 53.

R.W. McChesney, Corporate Media and the Threat to Democracy, New York 1997, s. 9. 
niem panującego porządku, nie zaś próbą kreacji nowej medialnej rzeczywistości.

Jeśli jednak przyjąć taką perspektywę modelu relacji mediów i polityki, należy zastanowić się, jaką rolę w modelu wolnorynkowym odgrywa ów drugi podmiot. Traktowanie nadawców i polityków jako elementów zupełnie na siebie nie oddziałujących zdaje się być nadmiernym uproszczeniem, nawet w rywalizacji na wolnym rynku mediów. Skoro media masowe osiągają jak największą oglądalność, to jaki ma to wpływ na politykę? Wydaje się, że odpowiedzi należy szukać w zjawisku komercjalizacji polityki. Źródła komercjalizacji mediów i polityki leżą z pewnością w powstaniu elektronicznych mediów prywatnych, które odciągnęły publiczność od nadawców publicznych ${ }^{13}$. Konsekwencje takiej komercjalizacji to przede wszystkim przybliżanie systemów medialnych do modelu rynkowego oraz zmian w społecznej funkcji dziennikarstwa. Zawód ten staje się głównie źródłem rozrywki i informacji, które można zaoferować masowej publiczności ${ }^{14}$. Również w procesie komunikowania politycznego rola komercjalizacji staje się coraz większa. Media, dzięki swoim możliwościom technicznym, są w stanie dotrzeć do coraz szerszej publiczności. Są przez to atrakcyjną formą prezentacji informacji politycznej. Aktorzy polityczni muszą z kolei dostosować swoją działalność do różnorodnych przekazów medialnych. Za pomocą mediów, stosunkowo małymi kosztami, mogą dotrzeć do masowej publiczności. Znajduje to odzwierciedlenie w tendencjach amerykanizacyjnych dyskursu politycznego oraz w znacznej personalizacji medialnego obrazu polityki. Analogiczna korzyść z komercjalizacji płynie do mediów. Te stają się nie tylko biernym przekaźnikiem wizerunków i idei politycznych, ale wywierają na nie znaczący wpływ. Już przez samo dostosowanie się aktorów politycznych do wymagań gry medialnej, nadawcy mogą kształtować odbiór wizerunku polityka czy partii. Ponadto, media starają sprostać się wymaganiom masowej publiczności, pokazując świat polityki zniekształcony, promując głównie rozrywkę, skandale i konflikty polityczne.

Przyjmując założenia modelu rynkowego, należy jeszcze raz podkreślić, że jego pierwotne traktowanie relacji mediów i polityki w sposób niejako czysty jest błędem. Co więcej, założenie, że owe relacje są transparentne ze względu na wolnorynkowy charakter mediów, przynosi zupełnie odmienne konstatacje. To właśnie rywalizacja na wolnym rynku doprowadza do wzajemnych ingerencji w treść politycznego komunikatu. Przy czym, należy

\footnotetext{
13 D. Hallin, P. Mancini, Systemy medialne. Trzy modele mediów i polityki w ujęciu porównawczym, Kraków 2007, s. 281.

14 Tamże, s. 283.
} 
zaznaczyć, że rolę nadrzędną w tych relacjach trzeba jednoznacznie przypisać nadawcom.

\section{Wnioski}

Wydaje się, że przedstawione powyżej analizy relacji mediów i polityki w oparciu o modele ideologiczne są jedynie przyczynkiem do pogłębionych badań tego zagadnienia. Badań, które w naturalny sposób musiałyby traktować zaprezentowane ujęcie w sposób czysty. Obierając owe modele jedynie jako pewne wzory, które należy rozbudować w zależności od tematu analiz. Jednak trzeba zwrócić uwagę na ważność zastosowania rozróżnienia ideologicznego w koncepcjach medialnych. Dzięki zastosowaniu siatki pojęć często z pogranicza filozofii, teorii komunikowania i mediów masowych otrzymujemy swoisty amalgamat, który daje szerokie pole do dalszych badań tematu. Charakterystyczna czystość metodologiczna modeli daje możliwość traktowania ich jako solidnej platformy, na której oprzeć można pracę.

Z drugiej strony, taką swoistą ogólnikowość można poczytać jako słabość modeli, bowiem traktują one oba systemy holistycznie, jako politykę i media masowe. W rzeczywistości mamy do czynienia z relacjami poszczególnych aktorów wewnątrzsystemowych. Możemy zatem mówić o relacjach polityków i dziennikarzy, partii i organizacji medialnych czy wreszcie systemu medialnego z systemem politycznym, a nawet mediokracji z demokracją. Przy czym, każdy z tych związków można rozpatrywać na wiele sposobów, spośród których najważniejszym jest badanie relacji dominacji i podporządkowania. Ów holizm może się przekładać na pewien chaos pojęciowy. Autorzy pisząc o polityce, stosują naprzemiennie przeróżne określenia opisujące jej podmioty, podobnie jak w przypadku opisu mediów. Kolejna słabość - to traktowanie danej ideologii w sposób absolutny. Niekiedy przyjmuje się określony paradygmat, któremu podporządkowana jest cała analiza. Owocuje to sprowadzeniem analizy do roli swoistego adwokata danej idei. 


\section{Abstract}

The most important issue of this paper is contained mostly, though vaguely, in the title. The ideological approach to mass media-politics relations is one of the most influential in communication science. The communication itself is treated here as essential to society, and its process can be expected to have a great effect upon the nature of a society, including politics. Media are so deeply involved in the system that without them, political activity could scarcely carry on at all.

In this paper, the author presents three most important ideologicaltheories of media-politics relations. We can consider them as the essential elements of opposite ideologies, liberalism and socialism. First one is Chomsky's and Herman's propaganda model. Briefly, this model shows how media are influenced by internal and external factors, and how it reflects news and form of published reality, called media reality. In fact, this model also shows how modern media systems are driven by corporations. Authors named five classes of filters in media system and society which determine news. In that case, we can consider the filters as five obstacles to gain freedom of speech: size, ownership and profit orientation of the mass media; advertising as the primary source of income of mass media; the reliance of the media on information provided by government, business and experts funded and approved by these primary sources and agents of power; "flak" as a means of disciplining the media; anticommunism as a national religion and control mechanism.

The second one is pluralist model. Here, media are treated as a channel, a messenger between the world of politics and the mass public. In this point journalists are considered to be impartial and their main goal is to show political reality in natural environment, with no influence on it. On the other hand, mass media play a role of guarantor of democratic procedures and first watchdog of political power - the forth estate.

The last one is market model, called liberal model. In this approach the key issue is free competition of media companies and concerns. Their main goal is gaining the best market position and multiplication of incomes. That is why media try to reach highest public. Moreover, politics can be a part of market and concerns compete also in this domain. 